\title{
Species richness and relative abundance of birds in natural and anthropogenic fragments of Brazilian Atlantic forest
}

\author{
LUIZ DOS ANJOS \\ Departamento de Biologia Animal e Vegetal, Universidade Estadual de Londrina, Cx. Postal 6001 \\ 86051-970 Londrina, PR, Brasil
}

Manuscript received on January 15, 2004; accepted for publication on February 5, 2004.

\begin{abstract}
Bird communities were studied in two types of fragmented habitat of Atlantic forest in the State of Paraná, southern Brazil; one consisted of forest fragments that were created as a result of human activities (forest remnants), the other consisted of a set of naturally occurring forest fragments (forest patches). Using quantitative data obtained by the point counts method in 3 forest patches and 3 forest remnants during one year, species richness and relative abundance were compared in those habitats, considering species groups according to their general feeding habits. Insectivores, omnivores, and frugivores presented similar general tendencies in both habitats (decrease of species number with decreasing size and increasing isolation of forest fragment). However, these tendencies were different, when considering the relative abundance data: the trunk insectivores presented the highest value in the smallest patch while the lowest relative abundance was in the smallest remnant. In the naturally fragmented landscape, time permitted that the loss of some species of trunk insectivores be compensated for the increase in abundance of other species. In contrast, the remnants essentially represented newly formed islands that are not yet at equilibrium and where future species losses would make them similar to the patches.
\end{abstract}

Key words: birds, bioacoustics, Brazilian Atlantic forest, conservation, forest fragmentation.

\section{INTRODUCTION}

The impressive biological diversity of tropical forests is seriously threatened by rapid and continuous deforestation. The scenario of forest loss in the tropics is dramatic (Whitmore 1997). However, species vary in their responses to forest fragmentation; while several species are extinct, others have benefited from forest fragmentation (Warburton 1997). Species that benefit from forest fragmentation tend to increase their relative abundance in the smallest and more isolated forest fragments principally due to (1) the increase in area of their habitats, as for edge species (Laurance et al. 1997),

E-mail: 1lanjos@sercomtel.com.br or (2) the release of competition with the extinction of their competitors, which has been termed density compensation (McArthur et al. 1972, Wright 1980).

The field method of point counts is commonly used around the world for studies on species richness and relative abundance of birds. The point counts method is essentially counting birds at previously determined points. Such counts are made based on birds seen and heard during a fixed period of time. In forest ecosystems, most of the contacts during the sampling time are heard but not seen. Especially in tropical forest, due to its high vegetation complexity, the ability to acoustically identify bird species has a quite important role. The point counts method was 
for the first time used in Brazil by Jacques Vielliard during the 1980's (Vielliard 2000). The first published work carried out in Brazil on the bird community using point counts was done in the interior of São Paulo State (Vielliard and Silva 1990). Since that time courses at the Brazilian Zoological and Ornithological Congresses have provided incentives for using the point counts method in Brazil. The number of published papers using point counts has increased steadily since 1990 . This increase is not comparable, however, to that in temperate regions. There are still only 16 papers using point counts published in Brazil, mostly in the States of São Paulo and Paraná, although additional unpublished results of academic theses exist.

In previous studies, species richness and relative abundance data on bird communities were obtained using the point counts method in two kinds of fragmented habitats in Paraná State, southern Brazil: one consisted of forest fragments that were created as a result of human activities (forest remnants; Anjos 2001), and the other consisted of a set of naturally occurring forest fragments (forest patches; Anjos and Boçon 1999). Forest remnants have been isolated for at least $40 \mathrm{yr}$ and forest patches for at least several centuries. More than $85 \%$ of the bird species occur in both sites. In both habitats, the total number of bird species decreased with decreasing forest fragment size and increasing isolation. Several species had the highest relative abundance in the smallest and the most isolated forest fragment in both habitats (Anjos and Boçon 1999, Anjos 2001). Insectivorous birds that capture food in trunk and branches (mostly woodpeckers and woodcreepers) were quite sensitive to the size and isolation of forest patches (Anjos and Boçon 1999).

In the present study, data on species richness and relative abundance of birds are compared from those fragmented forest habitats in Paraná State, southern Brazil.

\section{MATERIALS AND METHODS}

The forest patches were located in the southern part of Paraná State $\left(25^{\circ} 15^{\prime} \mathrm{S}, 49^{\circ} 48^{\prime} \mathrm{W}\right)$ and the for- est remnants were in the northern portion of Paraná State, southern Brazil ( $\left.23^{\circ} 17^{\prime} \mathrm{S}, 5^{\circ} 15^{\prime} \mathrm{W}\right)$. Three forest patches studied by Anjos and Boçon (1999) and three forest remnants studied by Anjos (2001) were selected for comparison in the present study. These fragments were selected for their similar size and isolation in both habitats. The three forest patches are: PA (840ha), PB (20ha), and PC (9ha). $\mathrm{PB}$ is linked to PA by a forest corridor, $1000 \mathrm{~m}$ long and $100 \mathrm{~m}$ wide, and PC, completely isolated, is $2000 \mathrm{~m}$ from PA. The three forest remnants are: RA (656ha), RB (25ha) and RC (11ha). RB is linked to RA by a forest corridor, $400 \mathrm{~m}$ long and $100 \mathrm{~m}$ wide, and RC, completely isolated, is $1100 \mathrm{~m}$ from RA. Grassland is the matrix habitat surrounding the forest patches while plantations of soya beans are the main matrix habitat surrounding the forest remnants. Therefore, connectivity between the fragments is low in both habitats. Patches and remnants are both Atlantic forest, but of different types: patches consist of mixed temperate rain forest, where Araucaria angustifolia (Araucariaceae) is the dominant tree, while remnants are seasonal semi-deciduous forest where Aspidosperma polyneuron (Apocynaceae) is the dominant tree. In the studied fragments, hunting and logging are not permitted by the owners. Vegetation is well preserved in all forest fragments. PA and RA have been permanent preservation areas since 1999 and 1989 respectively. For more details on locations, vegetation descriptions, and climatic features see Anjos and Boçon (1999) for forest patches and Anjos (2001) for forest remnants.

Species richness and relative abundance in forest patches and forest remnants were determined by monthly point counts of unlimited distance (Blondel et al. 1970). Since six point counts were performed per day each month in each forest patch, but only five in the forest remnants, the last sampling of each day in the forest patches was disregarded, thereby standardizing data to a total of 60 samples in each forest fragment (Anjos and Boçon 1999, Anjos 2001). Distances were $100 \mathrm{~m}$ between the points and $50 \mathrm{~m}$ between the points and the nearest edge. The points inside the largest forest patch and the largest forest 


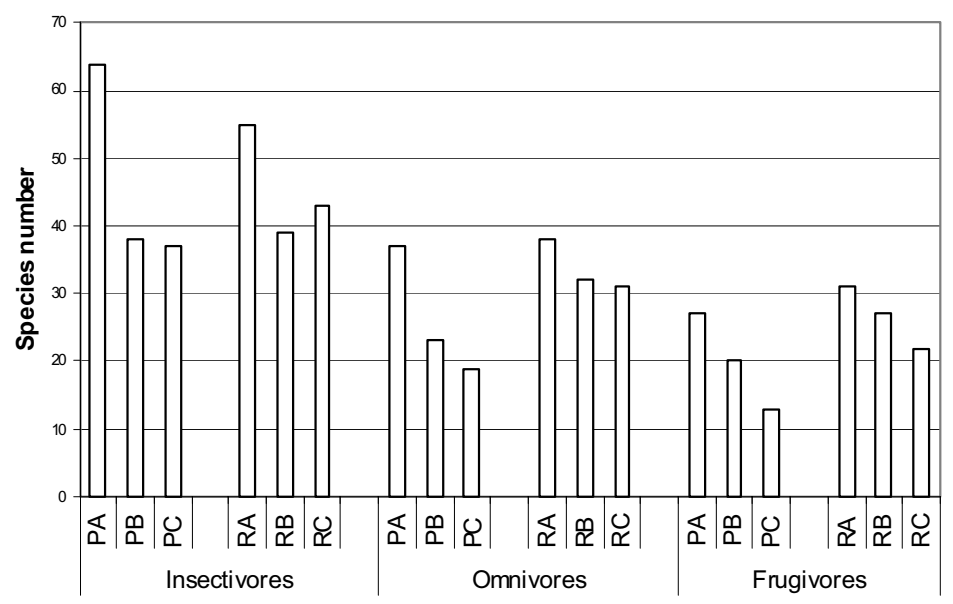

Fig. 1 - Total species number of insectivorous, omnivorous, and frugivorous birds in the forest patches (PA-PC) and in the forest remnants (RA-RC).

remnant were distributed within an estimated area of 70-80 ha. In the other forest fragments, points occupied the respective total areas. For the purpose of data comparisons, the forest areas were considered to be homogenous in each forest fragment.

A first comparison between the fragmented habitats was to consider the number of species (species richness) and their relative abundance for insectivorous, omnivorous, and frugivorous birds, excluding data from nectarivores and carnivores. A second comparison was carried out using data on insectivores that capture food in trunk and branches, which we call trunk insectivores.

The total number of contacts, i.e. a pair or a flock seen or heard by the observer, of each bird species obtained through point counts in each fragment was used for statistical calculations. Differences in the number of species and number of contacts for insectivores, omnivores and frugivores were tested between patches and remnants with a $G$-test $(\alpha=0.05)$ to a contingency table.

\section{RESULTS}

The effects of forest fragment size and isolation on the number of insectivorous $(G$-test $=1.10, \mathrm{df}=2$, $P>0.5)$, omnivorous $(G$-test $=1.68 ; \mathrm{df}=2 ; P>$ $0.3)$, and frugivorous $(G$-test $=0.76, \mathrm{df}=2, P>$
0.5) species were similar in both habitats (Fig. 1). However, the effect of these variables on the number of contacts ( $G$-test, $\mathrm{df}=2, P<0.05$; Fig. 2) were significantly different for all three groups.

The number of species of trunk insectivores was affected in a similar way in both habitats $(G-$ test $=0.36, \mathrm{df}=2, P>0.8$; Fig. 3). However, the relative abundance of trunk insectivores was highest in the smallest patch, but lowest in the smallest remnant; the high relative abundance in the smallest patch is due to the increased abundance of some species of that guild (Fig. 3). In the anthropogenic habitat, the trunk insectivores clearly decreased in number of contacts with size and isolation of the forest remnants. The mean number of contacts per species of that guild was 0.21 in PA and 0.43 in PC while they were 0.32 in RA and only 0.17 in RC.

\section{DISCUSSION}

The relative abundance of both species and contacts, for insectivores, omnivores and frugivores, considered as groups, tended to be affected in similar ways in both forest patches and remnants. The difference between these habitats becomes apparent when a guild, such as the trunk insectivores, is analyzed separately. The release of competition, due to a smaller species number, is probably the reason for 


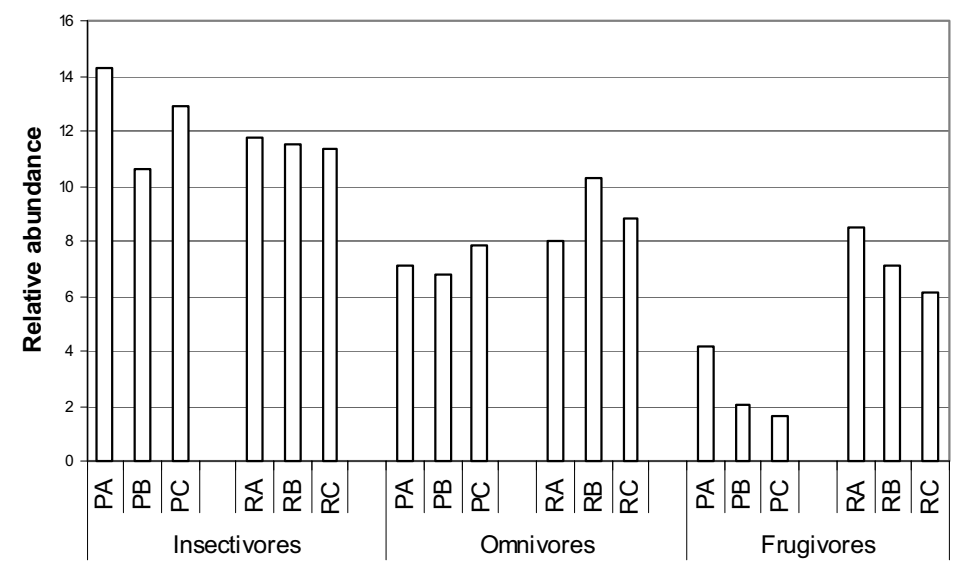

Fig. 2 - Total relative abundance of insectivorous, omnivorous, and frugivorous birds in the forest patches (PA-PC) and in the forest remnants (RA-RC).

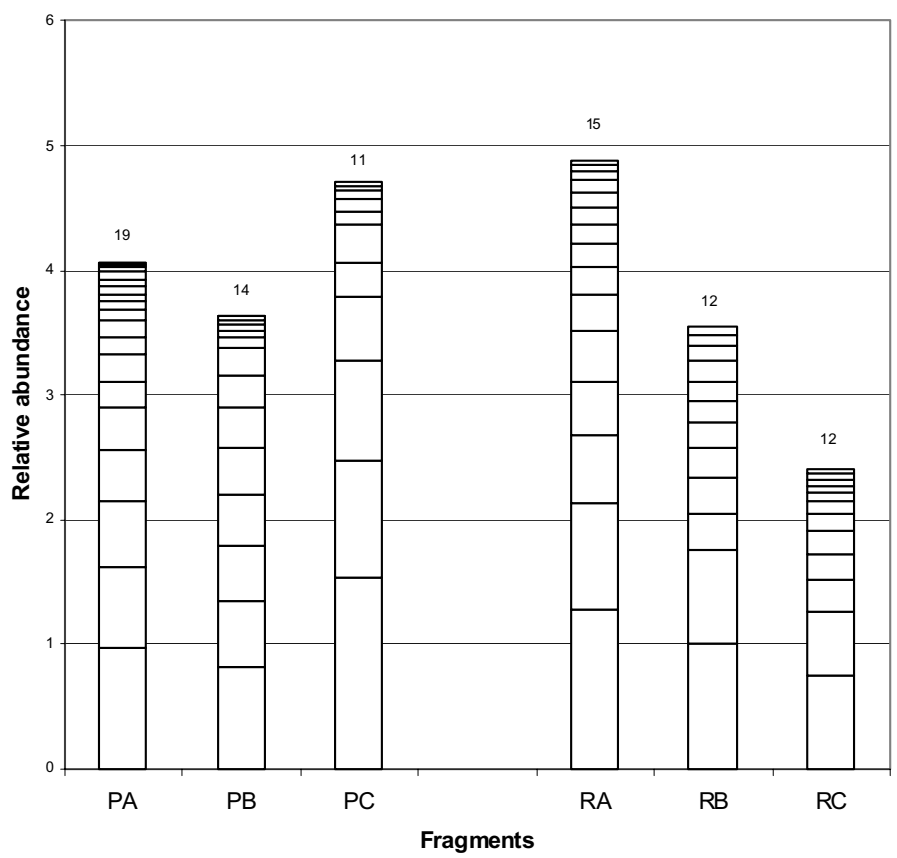

Fig. 3 - Total species number (numbers at the top of each column) and total relative abundance of trunk insectivores in the forest patches (PA-PC) and in the forest remnants (RA-RC). The segments in each column are the relative abundance of each species.

the higher relative abundance of some trunk insectivorous species in PC through density compensation. However, density compensation was not recorded for trunk insectivores in the smallest remnant RC, where the relative abundance of the species was very low compared to RA.

Reports on species persistence in forest remnants are surprisingly common in the literature, hav- 
ing been documented in several groups (Whitmore 1997). This means that the persistence of trunk insectivore populations in forest remnants is greater than would be expected. But are the populations of certain species in that guild large enough to be viable over a long time in the forest remnants? In the theory of island biogeography (McArthur and Wilson 1967), the number of species on an island results from a balance between rates of colonization and species extinction. Historically, this gradual process has presumably occurred to the species composition in the natural habitat composed of forest patches. In that case, time permitted the loss of some species in the guild of the trunk insectivores to be compensated for an increase in the abundance of others. The remnants essentially represented newly formed islands that are not yet at equilibrium; future species loss would make the remnants similar to the patches. Extinctions will therefore probably occur in the smallest and the most isolated forest remnants and the remaining species will increase their populations.

The future scenario of species extinctions appears to hold dramatic changes for the bird communities in the smaller remnants. Considering conservation, the importance of evaluating and monitoring forest bird populations in the Neotropics, using the point counts method, is highlighted by the data presented here.

\section{ACKNOWLEDGMENTS}

This study was funded by CNPq (Conselho Nacional de Desenvolvimento Científico e Tecnológico) through the Mata Atlantica Program and a research grant (LdA-350054/95-9). W. Belton kindly revised the English and K.-L. Schuchmann revised an early draft of this manuscript.

\section{RESUMO}

Comunidades de aves foram estudadas em duas regiões fragmentadas de floresta Atlântica no Estado do Paraná, sul do Brasil; uma região é constituída de fragmentos florestais que foram criados como resultado de atividades humanas (remanescentes florestais) e a outra de um conjunto de fragmentos florestais naturais (manchas de floresta). Usando dados quantitativos (o método de contagens pontuais) previamente obtidos em 3 manchas de floresta e em 3 remanescentes florestais durante um ano, a riqueza e a abundância relativa de aves foram comparadas naqueles habitats considerando as espécies pelos seus hábitos alimentares. Insetívoros, omnívoros e frugívoros apresentaram tendências gerais similares em ambos os habitats, diminuindo o número de espécies com o tamanho menor e o isolamento maior do fragmento florestal. Entretanto essas tendências foram diferentes considerando dados da abundância relativa: os insetívoros de tronco mostraram o maior valor na menor mancha enquanto que a menor abundância relativa foi obtida no menor remanescente. Na paisagem naturalmente fragmentada, o tempo permitiu que a perda de algumas espécies de insetívoros de tronco fosse compensada pelo aumento na abundância das outras. Em contraste, os remanescentes representam essencialmente ilhas recém formadas que ainda não atingiram o equilíbrio e onde futuras perdas de espécies as fariam similares às manchas.

Palavras-chave: aves, bioacústica, Mata Atlântica brasileira, conservação, fragmentação florestal.

\section{REFERENCES}

Anjos L Dos. 2001. Bird communities in five Atlantic forest fragments in southern Brazil. Ornitol Neotrop 12: 11-27.

Anjos L dos And Boçon R. 1999. Bird communities in natural forest patches in southern Brazil. Wilson Bull 111: 397-414.

Blondel J, Ferry C and Frochot B. 1970. La méthode des indices ponctuels d'abondance (I.P.A.) ou des relevés d'avifaune par "stations d'écoute". Alauda 38: 55-71.

Laurance WF, BierregaArd Jr RO, Gascon C, DiDHAM RK, Smith AP, Lynam AJ, Viana VM, Lovejoy TE, Sieving KE, Sites JR JW, ANDERSEn M, Tocher MD, Kramer EA, Restrepo C And Moritz C. 1997. Tropical forest fragmentation: synthesis of a diverse and dynamic discipline. In: LAURANCE WF AND BIERREGAARD JR RO. (Eds), Tropical forest remnants: ecology, management, and conservation of fragmented communities. Chicago: University of Chicago Press, p. 502-514.

McArthur R AND WiLson EO. 1967. The theory of is- 
land biogeography. Princeton: Princeton University Press.

McArthur R, KaAr JR and Diamond JM. 1972. Density compensation in island faunas. Ecology 53: 330-342.

VIELliard JME. 2000. Bird community as an indicator of biodiversity: results from quantitative surveys in Brazil. An Acad Bras Cienc 72: 323-330.

Vielliard JME AND Silva WR. 1990. Nova metodologia de levantamento quantitativo e primeiros resultados no interior do Estado de São Paulo. In: IV Encontro de Anilhadores de Aves, Recife, Proceedings..., Recife: Universidade Federal de Pernambuco, p. 117-151.
WARBURTON NH. 1997. Structure and conservation of forest avifauna in isolated rainforest remnants in tropical Australia. In: LAURANCE WF AND BierreGAARD JR RO. (Eds), Tropical forest remnants: ecology, management, and conservation of fragmented communities. Chicago: University of Chicago Press, p. 190-206.

Whitmore TC. 1997. Tropical forest disturbance, disappearance, and species loss. In: LAURANCE WF AND BIERREGAARD JR RO. (Eds), Tropical forest remnants: ecology, management, and conservation of fragmented communities. Chicago: University of Chicago Press, p. 3-12.

Wright SJ. 1980. Density compensation in island avifaunas. Oecologia 45: 385-389. 